\title{
Use of indirect calorimetry to evaluate utilization of energy in lactating Jersey dairy cattle consuming diets with increasing inclusion of hydrolyzed feather meal
}

\author{
D. L. Morris, () J. V. Judy, and P. J. Kononoff* (1) \\ Department of Animal Science, University of Nebraska, Lincoln 68583
}

\begin{abstract}
A study using indirect calorimetry and 12 lactating multiparous Jersey cows $(53 \pm 23 \mathrm{~d}$ in milk at the beginning of the experiment; mean \pm standard deviation) was conducted to evaluate the utilization of energy in cattle consuming diets containing increasing hydrolyzed feather meal (HFM). A triplicated $4 \times 4$ Latin square design with 35 -d periods (28-d adaption and 4-d collections) was used to compare 4 different dietary treatments. Treatments contained (DM basis) HFM at $0 \%$ (0HFM), 3.3\% (3.3HFM), 6.7\% (6.7MFM), and $10.0 \%$ (10HFM). Diets were formulated such that HFM replaced blood meal and nonenzymatically browned soybean meal. With increasing HFM, linear increases were observed for dietary $\mathrm{NE}_{\mathrm{L}}$ content (1.61, $1.64,1.69$, and $1.70 \pm 0.042 \mathrm{Mcal} / \mathrm{kg}$ of $\mathrm{DM}$ for $0 \mathrm{HFM}$, 3.3HFM, 6.7MFM, and 10HFM, respectively), and the efficiency of converting $\mathrm{ME}$ to $\mathrm{NE}_{\mathrm{L}}(0.708,0.711,0.717$, and 0.719). Apparent total-tract digestibility of CP linearly decreased with increasing HFM (63.4, 61.1, 59.9, and $58.6 \pm 1.46 \%$ for 0HFM, 3.3HFM, 6.7MFM, and 10HFM, respectively), whereas long-chain fatty acid digestibility increased with increasing HFM (77.2, 77.7, 78.5 , and $80.6 \pm 1.30 \%)$. With increased inclusion of HFM, fecal N excretion increased (199, 230, 239, 237 $\pm 12.1 \mathrm{~g} / \mathrm{d}$ for 0HFM, 3.3HFM, 6.7MFM, and 10HFM, respectively), whereas urinary $\mathrm{N}$ excretion decreased $(166,151,155$, and $119 \pm 14.8 \mathrm{~g} / \mathrm{d})$. Increasing the concentration of HFM resulted in a quadratic effect on DMI $(19.6,20.2,20.3$, and $19.1 \pm 0.79 \mathrm{~kg} / \mathrm{d}$ for $0 \mathrm{HFM}$, 3.3HFM, 6.7MFM, and 10HFM, respectively) and milk yield $(31.7,32.0,31.9$, and $29.7 \pm 1.32 \mathrm{~kg} / \mathrm{d})$. Increasing HFM linearly decreased the milk protein concentration $(3.34,3.29,3.23$, and $3.23 \pm 0.158$ for $0 \mathrm{HFM}$, 3.3HFM, 6.7MFM, and 10HFM, respectively) and yield $(1.05,1.05,1.02$, and $0.96 \pm 0.040 \mathrm{~kg})$. The inclusion of
\end{abstract}

\footnotetext{
Received October 17, 2019.

Accepted January 16, 2020

*Corresponding author: pkononoff2@unl.edu
}

HFM did not affect energy-correct milk yield (average of $39.3 \pm 1.54$ ). Results of this study suggest that HFM can increase dietary $\mathrm{NE}_{\mathrm{L}}$ content compared with blood meal and nonenzymatically browned soybean meal and maintained energy-corrected milk yield; however, feeding HFM at greater than $6.7 \%$ of diet DM decreased DMI, and protein availability may have been reduced with increased HFM, leading to a linear decrease in milk protein concentration and yield.

Key words: hydrolyzed feather meal, digestibility, dairy cow, nutrition, energy

\section{INTRODUCTION}

The production of milk for human consumption has become more efficient over time. In an evaluation of inputs needed to produce 1 billion $\mathrm{kg}$ of milk, Capper et al. (2009) concluded that compared with 1944, dairy producers in 2007 used $21 \%$ fewer animals, $23 \%$ less feed, $35 \%$ less water, and $10 \%$ less land. In the United States and in confined housing systems, it is generally accepted that feed costs represent the single greatest cost to produce milk (Wolf, 2010). To reduce this expense, dairy producers often purchase byproduct feeds as a less costly source of nutrients to feed cattle (Bradford and Mullins, 2012). The use of feed byproducts also contributes to the sustainability of the dairy industry (Salami et al., 2019) and supports efficiencies of human food production. Byproducts represent a feed input that from a human consumption perspective would be considered a waste product (VandeHaar and St-Pierre, 2006). In support of this suggestion, Karlsson et al. (2018) reported that feeding diets containing a high proportion of byproducts, to replace human-edible cereal grains, resulted in a 3 -fold increase in humanedible feed conversion efficiency. A major challenge with byproducts is that although they are generally cost effective they vary in chemical composition and digestibility.

Hydrolyzed feather meal (HFM) is a feed byproduct produced from clean, undecomposed feathers that are 
cooked under pressure (AAFCO, 2016). The CP content of HFM is approximately $85 \%$, and when fed to dairy cattle, a high proportion of this protein bypasses rumen fermentation and directly supplies protein to the small intestine (NRC, 2001). Thus, HFM can be used to replace more expensive sources of RUP such as blood meal or nonenzymatically browned soybean meal. The intestinal digestibility of HFM protein may, however, be less than other commonly fed protein sources (Waltz et al., 1989). Surprisingly, only a few studies have sought to evaluate the inclusion of feather meal on nutrient utilization in dairy cattle (Rakes et al., 1968; Harris et al., 1992; Grant and Haddad, 1998). From these studies, the effects of HFM on DMI, milk yield, and milk protein yield were dependent on inclusion, dietary CP content, blood content of HFM, and digestibility of HFM. More recent studies in which diets were formulated to induce an AA deficiency have reported that HFM may result in decreased milk protein yield (Stahel et al., 2014; Giallongo et al., 2017). The crude fat content of HFM ranges from 6 to $14 \%$ of DM (Cotanch et al., 2007). Because dietary fat can increase dietary energy content (Andrew et al., 1991; NRC, 2001), increased inclusion of HFM may also affect energy utilization by lactating cows. Therefore, the objectives of this research was to evaluate the overall feeding value of HFM when fed to lactating dairy cattle and to test the effects of HFM on total-tract CP digestibility and energy utilization. We hypothesized that increased inclusion of HFM would decrease CP digestibility leading to decreased milk protein yield; however, due to the contribution of fat the supply of energy would increase.

\section{MATERIALS AND METHODS}

\section{Experimental Design, Animals, and Treatments}

The University of Nebraska-Lincoln Animal Care and Use Committee Animal approved animal care and experimental procedures. The experiment used 12 multiparous lactating Jersey cows averaging $( \pm \mathrm{SD}) 53$ \pm 28 DIM (21 to 107 ) and $445.3 \pm 45.2 \mathrm{~kg}$ of BW at the beginning of the experiment. Cows were housed in individual tiestalls equipped with rubber mats in a temperature-controlled $\left(20^{\circ} \mathrm{C}\right)$ barn at the Dairy Metabolism Facility in the Animal Science Complex at the University of Nebraska-Lincoln and milked at 0700, 1400, and $2100 \mathrm{~h}$, representing AM, midday, and PM milking. All cows were less than $63 \mathrm{~d}$ pregnant at the end of the last experimental period; thus, fetal energy was assumed to be zero (NRC, 2001).

The experimental design was a 3 times replicated $4 \times$ 4 Latin square with 35-d periods. Animals were blocked into each square by milk production. Treatments alter- nated over 4 experimental periods and measurements were collected on each animal consuming each treatment within the same period (Kononoff and Hanford, 2006). The study was conducted with a total of 4 experimental periods each being $35 \mathrm{~d}$ in duration. Each period included $28 \mathrm{~d}$ for ad libitum diet adaptation, targeting about $5 \%$ refusals during that time, followed by $4 \mathrm{~d}$ of collection with $4 \mathrm{~d}$ of $95 \%$ ad libitum feeding to reduce the amount of refusals.

Cows were fed 1 of 4 treatment diets that contained HFM on a DM basis at (1) $0 \%$ (OHFM), (2) $3.3 \%$ (3.3HFM); (3) $6.7 \%$ (6.7HFM); and (4) $10 \%$ (10HFM; Table 1). The HFM was a blend of 2 sources (Pilgrim's, Greeley, CO; Simmons Foods, Siloam Springs, AR). Target inclusion of HFM was achieved by replacing blood meal and nonenzymatically browned soybean meal. The TMR was mixed in a Calan Data Ranger (American Calan Inc., Northwood, NH) and fed once daily at $0900 \mathrm{~h}$.

\section{Laboratory Analysis}

Individual feed ingredients were sampled (500 g) on the first day of each collection period and frozen at $-20^{\circ} \mathrm{C}$ and later analyzed for DM (AOAC International, 2000), N (Leco FP-528 N Combustion Analyzer, Leco Corp., St. Joseph, MI), NDF with sodium sulfite (Van Soest et al., 1991), ADF (method 973.18; AOAC International, 2000), lignin (Goering and Van Soest, 1970), sugar (DuBois et al., 1956), starch (Hall, 2009), crude fat (2003.05; AOAC International, 2000), ash (943.05; AOAC International, 2000), and minerals (985.01; AOAC International, 2000) at Cumberland Valley Analytical Services Inc. (Hagerstown, MD). Gross energy (GE; Parr 6400 Calorimeter, Moline, IL) was measured at the University of Nebraska-Lincoln laboratory. Samples of HFM, blood meal, and nonenzymatically browned soybean meal were analyzed for RUP and digestible RUP according to Ross et al. (2013). Total mixed rations were sampled $(500 \mathrm{~g})$ on each day of each collection period and were frozen at $-20^{\circ} \mathrm{C}$. The TMR sample was used to determine particle size using the Penn State Particle Separator according to Heinrichs and Kononoff (2002). On each day of the collection period, refusals were sampled and frozen at $-20^{\circ} \mathrm{C}$. The samples were composited by period and individual cow. A subsample was sent to Cumberland Valley Analytical Services Inc. (Waynesboro, PA) for nutrient analysis of DM, N, NDF with sodium sulfite, starch, and ash as described previously. A subsample was also used to measure GE (Parr 6400 Calorimeter) at the University of Nebraska-Lincoln laboratory.

Total fecal and urine output was collected from each individual cow during the collection period for 4 con- 
secutive days. Personnel were assigned and present during all times of sample collections and when possible, manually collected feces with a 3-quart scoop (Miller Manufacturing, Eagan, MN) upon defecation, but when missed, feces landed on a $137 \times 76 \mathrm{~cm}$ rubber mat (Snake River Supply, Idaho Falls, ID) that was placed on the floor behind the cow and collected immediately. The feces were deposited multiple times a day from the rubber mats into a large 121-L (32 gallon) garbage container (Rubbermaid, Wooster, $\mathrm{OH}$ ) with a black garbage bag covering the top to reduce nitrogen losses before subsampling. The feces were subsampled (500 g) every day and dried at $60^{\circ} \mathrm{C}$ in a forced-air oven for $48 \mathrm{~h}$ and then composited by cow and period before being ground to pass through a 1-mm screen (Wiley mill, Arthur H. Thomas Co., Philadelphia, PA). The ground fecal sample were sent to Cumberland Valley Analytical Services Inc. (Waynesboro, PA) for nutrient analysis of DM, N, NDF with sodium sulfide, starch, and ash using the same methods as feed ingredients. Total urine was collected by inserting a 30-French Foley catheter into each cow's bladder with a stylus. The balloon was inflated to $55 \mathrm{~mL}$ with physiological saline and Tygon tubing drained into a plastic carboy (15

Table 1. Ingredient inclusion and chemical composition of treatments containing hydrolyzed feather meal (\% of DM unless otherwise indicated $)^{1}$

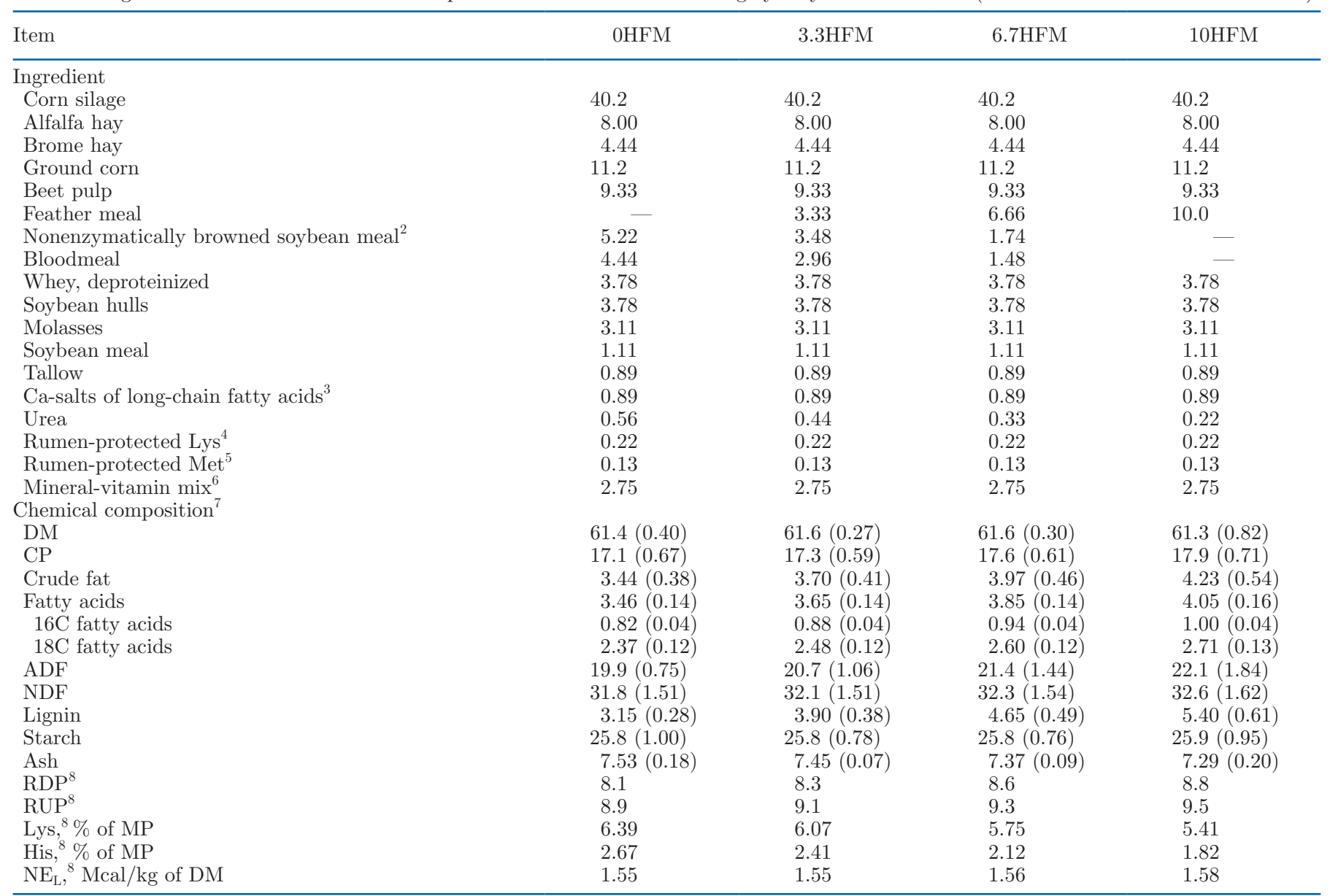

${ }^{1}$ Treatments: $0 \mathrm{HFM}=0 \%$ hydrolyzed feather meal; $3.3 \mathrm{HFM}=3.3 \%$ hydrolyzed feather meal; $6.7 \mathrm{HFM}=6.7 \%$ hydrolyzed feather meal; $10 \mathrm{HFM}$ $=10 \%$ hydrolyzed feather meal.

${ }^{2}$ Soypass (LignoTech, Overland Park, KS).

${ }^{3}$ Megalac (Church \& Dwight Co. Inc., Princeton, NJ).

${ }^{4}$ Ajipro (Ajinomoto, Chicago, IL).

${ }^{5}$ Smartamine M (Adisseo, Alpharetta, GA).

${ }^{6}$ Contained per kilogram: $403 \mathrm{~g}$ of $\mathrm{CaCO}_{3}, 204 \mathrm{~g}$ of $\mathrm{NaHCO}_{3}, 160 \mathrm{~g}$ of $\mathrm{Ca}_{2} \mathrm{PO}_{4}, 113 \mathrm{~g}$ of $\mathrm{MgO}, 87 \mathrm{~g}$ of salt, $18 \mathrm{~g}$ of vitamin premix $(14,850 \mathrm{IU} / \mathrm{g}$ vitamin A, 3,850 IU/g vitamin D, and $90 \mathrm{IU} / \mathrm{g}$ of vitamin E), and $15 \mathrm{~g}$ of trace mineral premix $(180,000 \mathrm{mg} / \mathrm{kg} \mathrm{Zn,} \mathrm{150,000} \mathrm{mg/kg} \mathrm{Mn,} \mathrm{25,000}$ $\mathrm{mg} / \mathrm{kg} \mathrm{Cu}, 2,600 \mathrm{mg} / \mathrm{kg} \mathrm{I}, 2,300 \mathrm{mg} / \mathrm{kg} \mathrm{Co}, 1,000 \mathrm{mg} / \mathrm{kg} \mathrm{Fe}$, and $820 \mathrm{mg} / \mathrm{kg} \mathrm{Se}$ ).

${ }^{7}$ Values determined by Cumberland Valley Analytical Services, Waynesboro, PA; values denoted as mean (SD).

${ }^{8}$ Estimated with NRC (2001) using mean DMI, and milk production and composition from Table 6. 
quart; Midwest Can Company, Franklin Park, IL) behind the cow. Using the funnel spout of the plastic carboy, urine was deposited into a 55-L plastic container 4 times a day and was acidified with $100 \mathrm{~mL}$ of $\mathrm{HCl}$ before subsampling $(500 \mathrm{~mL})$. Daily subsamples were frozen at $-20^{\circ} \mathrm{C}$ until analysis. Before analysis urine was thawed and boiled to remove the water. To boil the urine, samples were placed in a $600-\mathrm{mL}$ beaker in a boiling water bath (Ankom Technology, Macedon, NY). After water was boiled away, the remaining paste was lyophilized (VirTis Freezemobile 25ES, SP Scientific, Gardiner, NY). Once lyophilized, sample size was reduced using mortar and pestle and then analyzed at the University of Nebraska-Lincoln for DM $\left(100^{\circ} \mathrm{C}\right.$ oven for $24 \mathrm{~h}$ ), N (Leco FP-528, Leco Corp.), and GE (Parr 6400 Calorimeter).

Milk production was measured daily and milk samples were collected during the AM, midday, and PM milking times for 4 consecutive days at the end of each period. Two tubes were collected during each milking $(100 \mathrm{~mL})$; one $50-\mathrm{mL}$ conical tube was frozen at $-20^{\circ} \mathrm{C}$ and one tube was sent off to DHIA preserved using 2-bromo-2-nitropropane-1,3 diol. Samples were sent to Heart of America DHIA (Kansas City, MO) and were analyzed for fat, protein, lactose, and MUN using a Bentley FTS/FCM Infrared Analyzer (Bentley Instruments, Chaska, MN). The frozen milk sample was lyophilized and composited by cow and period for nutrient analysis. Milk samples were analyzed at the University of Nebraska-Lincoln for DM, N, and GE using the same methods as were used for urine. To determine DM output, feed ingredient, refusals, feces, and urine samples were dried at $60^{\circ} \mathrm{C}$ in a forced-air oven for $48 \mathrm{~h}$ and milk samples were lyophilized. Feed ingredients, refusals, and feces were ground as previously described with the feces. Water intake was measured using DLJGHT garden hose water meter (DLJ Meter, Hackensack, NJ) while each cow was inside the headbox.

Heat production was determined through the headbox-type indirect calorimeters as described previously (Freetly et al., 2006; Foth et al., 2015). For each cow, a collection period of 23 -h was used to measure $\mathrm{O}_{2}$ consumption and $\mathrm{CO}_{2}$ and $\mathrm{CH}_{4}$ production. Gas data were adjusted to a 24 -h period. Four headboxes were used and data were collected across $3 \mathrm{~d}$ during the 4 -d collection period. Cows were adapted to headboxes for a minimum for $3 \mathrm{~d}$ before the start of the experiment. Feed was placed in the bottom of the headbox and cows were allowed ad libitum access to water from a water bowl placed inside the headbox. Free water intake was measured using a water meter (model DLJSJ75, Daniel L. Jerman Co., Hackensack, NJ) while each cow was inside the headbox. Within the headbox, temperature and dew point were measured every minute during the 23-h collection interval using a probe (model TRH-100, Pace Scientific Inc., Moorseville, NC) and recorded using a data logger (model XR440, Pace Scientific Inc.). Line pressure was measured using a u-tube manometer (item 1221-8, Park Supply of America Inc., Minneapolis, MN) and barometric pressure of the room was measured using a barometer (Chaney Instruments Co., Lake Geneva, WI). Total volume of air flow through the headbox was measured using a gas meter (model AL425, American Meter, Horsham, PA) and corrected to standard temperature and pressure $\left(0^{\circ} \mathrm{C}, 101.3\right.$ $\mathrm{kPa}$ ) with adjustment for moisture content of exhaust air (Nienaber and Maddy, 1985). From the headbox, continuous samples of incoming and outgoing air were collected into separate aluminum Mylar bags (44 L, LAM-JAPCON-NSE, Pollution Measurement Corp., Oak Park, IL) using glass tube rotameters (model 1350E Sho-Rate "50," Brooks Instruments, Hatfield, $\mathrm{PA}$ ). Gas bags were analyzed for $\mathrm{O}_{2}, \mathrm{CO}_{2}$, and $\mathrm{CH}_{4}$ using an Emerson X-stream 3-channel analyzer (Solon, $\mathrm{OH})$ according to the method of Nienaber and Maddy (1985). Before the start of the experiment, system efficiency (head box and gas analyzer) was determined by burning $100 \%$ ethyl alcohol and measuring gas recoveries. Recoveries of $\mathrm{O}_{2}$ consumption and $\mathrm{CO}_{2}$ production were (average \pm SD) $101.0 \pm 0.04 \%$ and $100.8 \pm 0.04 \%$, respectively.

\section{Energy Calculations}

Calculations for digestible energy (DE) and ME were as follows:

$$
\begin{aligned}
\operatorname{DE}(\mathrm{Mcal} / \mathrm{d}) & =\mathrm{GE}(\mathrm{Mcal} / \mathrm{d})-\text { fecal energy }(\mathrm{Mcal} / \mathrm{d}), \\
\mathrm{ME}(\mathrm{Mcal} / \mathrm{d}) & =\operatorname{DE}(\mathrm{Mcal} / \mathrm{d}) \text { - urine energy }(\mathrm{Mcal} / \mathrm{d}) \\
& - \text { methane energy }(\mathrm{Mcal} / \mathrm{d}) .
\end{aligned}
$$

Heat production (HP) was estimated as follows (Brouwer, 1965):

$$
\begin{gathered}
\mathrm{HP}(\mathrm{kcal} / \mathrm{d})=3.866 \times \mathrm{O}_{2}(\mathrm{~L} / \mathrm{d}) \\
+1.200 \times \mathrm{CO}_{2}(\mathrm{~L} / \mathrm{d})-0.518 \times \mathrm{CH}_{4}(\mathrm{~L} / \mathrm{d}) \\
-1.431 \times \text { urinary } \mathrm{N} \text { excretion }(\mathrm{g} / \mathrm{d}) .
\end{gathered}
$$

The respiratory quotient was calculated using the ratio of carbon dioxide produced to oxygen consumed (L/L). Methane energy was estimated by multiplying $\mathrm{CH}_{4}$ pro- 
duction by its enthalpy $(9.45 \mathrm{kcal} / \mathrm{L})$. Unaccounted for energy was assumed to represent tissue energy, which was expressed on an $\mathrm{NE}_{\mathrm{L}}$ basis as follows:

$$
\begin{gathered}
\text { residual energy }(\mathrm{Mcal} / \mathrm{d})=\mathrm{ME}(\mathrm{Mcal} / \mathrm{d}) \\
-\mathrm{HP}(\mathrm{Mcal} / \mathrm{d})-\text { milk energy }(\mathrm{Mcal} / \mathrm{d}) \text {. } \\
\text { Tissue energy }\left(\mathbf{T E} \text {; Mcal of } \mathrm{NE}_{\mathrm{L}} / \mathrm{d}\right)= \\
\text { positive residual energy } \\
\times \mathrm{k}_{\mathrm{T}} \text { or negative residual energy } \times \mathrm{k}_{\mathrm{G}} / \mathrm{k}_{\mathrm{L}} \text {, }
\end{gathered}
$$

where $k_{T}$ is the efficiency of utilizing body reserves for milk energy production, $\mathrm{k}_{\mathrm{G}}$ is the efficiency of utilizing $\mathrm{ME}$ intake for tissue gain, and $\mathrm{k}_{\mathrm{L}}$ is the efficiency of utilizing ME intake for milk production. Values of 0.89, 0.75 , and 0.66 were used for $\mathrm{k}_{\mathrm{T}}, \mathrm{k}_{\mathrm{G}}$, and $\mathrm{k}_{\mathrm{L}}$, respectively (Moraes et al., 2015). Calculations for $\mathrm{NE}_{\mathrm{L}}$ was as follows:

$$
\begin{aligned}
& \mathrm{NE}_{\mathrm{L}}(\mathrm{Mcal} / \mathrm{d})=\text { milk energy }\left(\text { Mcal of } \mathrm{NE}_{\mathrm{L}} / \mathrm{d}\right) \\
& +\mathrm{TE}\left(\text { Mcal of } \mathrm{NE}_{\mathrm{L}} / \mathrm{d}\right)+0.080 \times \mathrm{BW}(\mathrm{kg})^{0.75}
\end{aligned}
$$

Tissue energy for body protein and fat deposit was calculated as follows (Freetly et al., 2006; van Knegsel et al., 2007):

$$
\begin{gathered}
\text { TE as body protein }\left(\mathrm{TE}_{\mathrm{P}} ; \mathrm{Mcal} / \mathrm{d}\right)= \\
\text { retained } \mathrm{N}(\mathrm{g} / \mathrm{d}) \times 5.88(\mathrm{~g} \text { of protein } / \mathrm{g} \text { of } \mathrm{N}) \\
\times 0.0057(\mathrm{Mcal} / \mathrm{g} \text { of protein }),
\end{gathered}
$$

TE as body fat $(\mathrm{Mcal} / \mathrm{d})=\mathrm{TE}(\mathrm{Mcal} / \mathrm{d})$

$$
-\mathrm{TE}_{\mathrm{P}}(\mathrm{Mcal} / \mathrm{d}) \text {. }
$$

We determined $\mathrm{NE}_{\mathrm{M}}$ and $\mathrm{k}_{\mathrm{L}}$ as described by Kebreab et al. (2003). For this, ME was corrected for the ME that was used for tissue retention and milk energy was corrected for milk energy from tissue mobilization. Corrected ME and milk energy were calculated as follows:

$$
\begin{gathered}
\text { corrected } \mathrm{ME}=\mathrm{ME}(\mathrm{kg} / \mathrm{d}) \\
-\mid \text { positive residual energy }(\mathrm{Mcal} / \mathrm{d}) \mid / \mathrm{k}_{\mathrm{G}},
\end{gathered}
$$

corrected milk energy = milk energy $(\mathrm{Mcal} / \mathrm{d})$

$$
\text { - } \mid \text { negative residual energy }(\mathrm{Mcal} / \mathrm{d}) \mid \times \mathrm{k}_{\mathrm{T}}, \quad[10]
$$

where $\mathrm{k}_{\mathrm{G}}$ and $\mathrm{k}_{\mathrm{T}}$ are as described above. Corrected ME and corrected milk energy were expressed as a function of metabolic body weight $\left(\mathbf{M B W} ; \mathrm{kg}^{0.75}\right)$.

\section{Statistical Analysis}

Data were analyzed in R (v3.5.1) using the lmer package (Kuznetsova et al., 2017). The model included the fixed effects of treatment and the random effect of period, square, and cow nested in square. To determine $\mathrm{NE}_{\mathrm{M}}$ and $\mathrm{k}_{\mathrm{L}}$, corrected milk energy was regressed against the fixed effect of treatment and the interaction of treatment with corrected ME. Random effects of period, square, and cow nested in square were included. The fixed effect of treatment was not significant $(P=$ 0.55 ) and was thus removed. Linear, quadratic, and cubic effects of treatments were tested using the emmeans package (Lenth, 2018). All data are presented as least squares means \pm largest standard error. Significance was declared at $P \leq 0.10$.

\section{RESULTS AND DISCUSSION}

This experiment was designed to test the effects of replacing blood meal and nonenzymatically browned soybean meal with HFM on energy and $\mathrm{N}$ utilization, DMI, and milk production and composition. Compared with feeding a diet with soybean meal, total-tract CP digestibility of diets containing HFM are often lower (Waltz et al., 1989; Harris et al., 1992), and decreased milk protein concentration has also been observed (Harris et al., 1992). Furthermore, the crude fat content of HFM can be as high as $14 \%$ of DM (Cotanch et al., 2007); therefore, increased inclusion of HFM may increase dietary energy density. We expected that increased HFM inclusion would decrease digestible protein supply leading to decreased milk protein yield, while dietary energy density would increase.

Increasing inclusion of HFM increased CP from 17.1 to 17.9 and fatty acids from 3.46 to $4.05 \%$ of diet DM (Table 1). The blend of HFM from 2 sources used in the current study was (mean $\pm \mathrm{SD}$ ) $92.5 \pm 2.12 \% \mathrm{CP}$ and $7.5 \pm 0.26 \%$ crude fat (Table 2). When analyzed according to Ross et al. (2013), estimated total-tract digestible CP for the HFM blend, blood meal, and nonenzymatically browned soybean meal was (mean \pm SD) $50.3 \pm 1.98,94.3$, and $98.0 \%$ of CP, respectively. We have recently reported that the ruminal and intestinal digestibility of HFM can be highly variable and dependent on processing methods (Buse et al., 2019). Tabular values for RUP of HFM, blood meal, and nonenzymatically browned soybean meal for a cow eating a $50 \%$ roughage diet at $4.0 \%$ of $\mathrm{BW}$ are $65.4,77.5$, and $79.4 \%$ of CP, respectively, and the RUP digestibility values are 65,80 , and $93 \%$, respectively (NRC, 2001). Therefore, using NRC (2001), estimated RDP content increased with increasing HFM inclusion (8.1 to $8.8 \%$ of $\mathrm{DM}$ for $0 \mathrm{HFM}$ and $10 \mathrm{HFM}$, respectively). 
Table 2. Feed chemical analysis for alfalfa hay, brome hay, corn silage, and concentrate mixes (\% of DM) ${ }^{1,2}$



${ }^{1}$ Mean and SD $(n=4)$ were calculated based on samples of each feedstuff collected during each period and estimated by a commercial feed testing laboratory (Cumberland Valley Analytical Services, Waynesboro, PA).

${ }^{2} 0 \mathrm{HFM}$ concentrate $=$ concentration with $0 \%$ hydrolyzed feather meal; $10 \mathrm{HFM}=$ concentration with $10 \%$ hydrolyzed feather meal $(\mathrm{n}=4)$.

${ }^{3} \mathrm{ADICP}=$ acid detergent insoluble crude protein; NDICP $=$ neutral detergent insoluble crude protein.

${ }^{4} \mathrm{HFM}=$ hydrolyzed feather meal blend from 2 sources (Pilgrim's, Greeley, CO; Simmons Foods, Siloam Springs, AR).

${ }^{5}$ Not determined.

This resulted in estimated RDP supplies that increased with increasing HFM inclusion, but were below NRC (2001) recommendations (RDP balance of $-321,-276$, -228 , and $-195 \mathrm{~g} / \mathrm{d}$ for OHFM, 3.3HFM, 6.7MFM, and 10HFM, respectively). For HFM, Lys and His content are lower than blood meal and nonenzymatically browned soybean meal, leading to decreased estimated Lys (6.39 to $5.41 \%$ of MP) and His (2.67 to $1.82 \%$ of MP) supply as HFM inclusion increased (NRC, 2001). Particle size distribution of TMR was similar across treatments (Supplemental Table S1; https://doi.org/10 $.3168 /$ jds.2019-17762).

\section{Gas Consumption and Production and Energy Utilization}

To assess the effects of placing animals in the headbox-style indirect calorimeter on feeding behavior, we compared DMI for when cows were in the headboxes to when cows were out of the headboxes. When cows were placed in headboxes, DMI decreased $(P=0.02)$ compared with when cows were not in the headboxes (19.3 vs. $20.1 \pm 0.73 \mathrm{~kg} / \mathrm{d}$; data not shown). However, no interactions between treatment or period with headbox placement were observed $(P>0.76$; data not shown) and differences between treatment effects for energy partitioning may be interpreted with confidence. De- spite the fact that we strived to make animals comfortable and familiar with the peculiar experimental setting, the modest reduction in DMI was not unexpected but still within normal ranges, and we are unaware of alternative techniques that would allow us to make the measurements described here.

Oxidation of carbohydrates, lipids, and protein, individually, give rise to a unique and nearly fixed quantity of heat per unit of $\mathrm{O}_{2}$ consumed and $\mathrm{CO}_{2}$ produced (McLean and Tobin, 1987). This principle is applied in the Brouwer (1965) equation when measurements of $\mathrm{O}_{2}$ consumption and $\mathrm{CO}_{2}$ production, along with correction for $\mathrm{CH}_{4}$ production and urinary $\mathrm{N}$ excretion, are used to indirectly estimate heat production. In the current study, $\mathrm{O}_{2}$ consumption and $\mathrm{CO}_{2}$ and $\mathrm{CH}_{4}$ production quadratically increased $(P<0.07)$ from $0 \mathrm{HFM}$ to $6.7 \mathrm{HFM}$ but then decreased when cows consumed 10HFM (Table 3). Consequently, a similar quadratic response $(P<0.07)$ was observed for methane energy and heat production. Because increased DMI typically leads to increased heat production (Purwanto et al., 1990; Reynolds et al., 1991), the quadratic relationship for gas variables and heat production were likely due to a similar quadratic relationship in DMI (see later discussion).

The replacement of blood meal and nonenzymatically browned soybean meal with HFM linearly increased $(P$ 
$<0.01)$ the GE content of the diet. Similar to GE content, $\mathrm{DE}, \mathrm{ME}$, and $\mathrm{NE}_{\mathrm{L}}$ content linearly increased $(P<$ 0.02) with increasing HFM. Increased dietary GE, DE, $\mathrm{ME}$, and $\mathrm{NE}_{\mathrm{L}}$ content may have been due to increased fatty acid content, which inherently possesses a greater enthalpy (9.4 Mcal $/ \mathrm{kg}$ of DM) than either CP (5.6) or NDF (4.2; NRC, 2001). In agreement, Andrew et al. (1991) reported increased dietary $\mathrm{NE}_{\mathrm{L}}$ concentration when supplementing Ca-salts of fatty acids. Increased dietary energy content supported similar $(P>0.37)$ milk energy output (average of $25.5 \pm 1.17 \mathrm{Mcal} / \mathrm{d}$ ) and tissue energy $\left(-0.50 \pm 1.50 \mathrm{Mcal}\right.$ of $\left.\mathrm{NE}_{\mathrm{L}} / \mathrm{d}\right)$, whereas DMI quadratically decreased.

Estimated $\mathrm{NE}_{\mathrm{M}}$ for the current experiment was not affected $(P>0.55)$ by treatment (average of $97.9 \pm 21.2$ kcal/MBW; Figure 1). Our estimated $\mathrm{NE}_{\mathrm{M}}$ is greater than that used by the current NRC (2001; $80 \mathrm{kcal} /$ $\mathrm{MBW}$ ). However, our observations fall within range reported by others who have determined $\mathrm{NE}_{\mathrm{M}}$ for cows fed at production levels of intake and these range from 74 to $124 \mathrm{kcal} / \mathrm{MBW}$ (Moe et al., 1972; Kebreab et al., 2003; Moraes et al., 2015). It has been suggested that
$\mathrm{NE}_{\mathrm{M}}$ has increased over time in lactating dairy cows and may at least in part be due to a concurrent increase in genetic merit of cows (Moraes et al., 2015). Interestingly, the large variance that we observed for $\mathrm{NE}_{\mathrm{M}}$ (21.7\% of mean), in part, demonstrates the challenge of estimating $\mathrm{NE}_{\mathrm{M}}$ requirements for cows, particularly for cows at a high plane of production. The $\mathrm{k}_{\mathrm{L}}$ linearly increased $(P=0.07)$ with increasing HFM. This increase in efficiency may have occurred due to an increase in the fat content of the diet, which is suggested to have a lower heat increment compared with energy that is derived from the basal diet (NRC, 2001). Andrew et al. (1991) calculated the $\mathrm{k}_{\mathrm{L}}$ for Ca-salts of long-chain fatty acids as 0.77 , which is greater than the previously reported $\mathrm{k}_{\mathrm{L}}$ for basal diets of 0.64 (Moe et al., 1972). An evaluation of historical studies has suggested that $\mathrm{k}_{\mathrm{L}}$ has increased since the 1960s and this may in part be explained by increased inclusion of supplemental fat (Moraes et al., 2015). Furthermore, an increase in the ratio of milk fat to milk protein in the current study with increasing HFM inclusion may have increased $\mathrm{k}_{\mathrm{L}}$ because synthesis of milk fat is thought to be more

Table 3. Effects of treatments containing hydrolyzed feather meal fed to lactating Jersey cows on $\mathrm{O}_{2}$ consumption, $\mathrm{CO}_{2}$ and $\mathrm{CH}_{4}$ production, respiratory quotient, and energy utilization

\begin{tabular}{|c|c|c|c|c|c|c|c|c|}
\hline Item $^{1}$ & \multicolumn{4}{|c|}{ Treatment $^{2,3}$} & SEM & \multicolumn{3}{|c|}{$P$-value ${ }^{4}$} \\
\hline $\mathrm{O}_{2}$ consumption, $\mathrm{L} / \mathrm{d}$ & 4,761 & 4,822 & 4,826 & 4,616 & 163 & 0.11 & 0.03 & 0.56 \\
\hline $\mathrm{CO}_{2}$ production, $\mathrm{L} / \mathrm{d}$ & 4,884 & 4,954 & 4,959 & 4,707 & 193 & 0.11 & 0.03 & 0.55 \\
\hline $\mathrm{CH}_{4}$ production, L/d & 420 & 434 & 433 & 403 & 24 & 0.30 & 0.06 & 0.75 \\
\hline RQ & 1.025 & 1.025 & 1.027 & 1.019 & 0.012 & 0.50 & 0.48 & 0.56 \\
\hline Methane & 4.12 & 4.25 & 4.24 & 3.94 & 0.235 & 0.29 & 0.07 & 0.75 \\
\hline Urine & 2.08 & 2.15 & 2.21 & 1.95 & 0.131 & 0.46 & 0.13 & 0.55 \\
\hline Heat $^{5}$ & 23.8 & 24.1 & 24.2 & 23.1 & 0.84 & 0.13 & 0.03 & 0.58 \\
\hline Milk & 25.3 & 25.2 & 26.6 & 25.0 & 1.17 & 0.90 & 0.37 & 0.21 \\
\hline Tissue $^{6}$ & -1.57 & 0.27 & -0.27 & -0.43 & 1.50 & 0.62 & 0.44 & 0.63 \\
\hline \multicolumn{9}{|l|}{ Fraction, Mcal/d } \\
\hline GE & 82.2 & 85.7 & 86.4 & 81.9 & 3.42 & 0.95 & 0.02 & 0.75 \\
\hline $\mathrm{DE}$ & 2.77 & 2.79 & 2.82 & 2.84 & 0.039 & 0.02 & 0.87 & 0.73 \\
\hline ME & 2.45 & 2.47 & 2.50 & 2.53 & 0.040 & 0.02 & 0.97 & 0.86 \\
\hline $\mathrm{NE}_{\mathrm{L}}^{7}$ & 1.61 & 1.64 & 1.69 & 1.70 & 0.042 & 0.02 & 0.57 & 0.64 \\
\hline
\end{tabular}

${ }^{1} \mathrm{GE}=$ gross energy; $\mathrm{DE}=$ digestible energy; $\mathrm{RQ}=$ respiratory quotient, $\mathrm{CO}_{2}$ production $/ \mathrm{O}_{2}$ consumption, $\mathrm{L} / \mathrm{L}$.

${ }^{2}$ Treatments: $0 \mathrm{HFM}=0 \%$ hydrolyzed feather meal; $3.3 \mathrm{HFM}=3.3 \%$ hydrolyzed feather meal; $6.7 \mathrm{HFM}=6.7 \%$ hydrolyzed feather meal; $10 \mathrm{HFM}$ $=10 \%$ hydrolyzed feather meal.

${ }^{3}$ Least squares means; largest standard error of treatment mean is shown.

${ }^{4} \mathrm{~L}=$ linear; $\mathrm{Q}=$ quadratic; $\mathrm{C}=$ cubic.

${ }^{5}$ Heat $=3.866 \times \mathrm{O}_{2}+1.200 \times \mathrm{CO}_{2}-0.518 \times \mathrm{CH}_{4}-1.431 \times \mathrm{N}$ (Brouwer, 1965).

${ }^{6}$ Tissue $=$ positive residual energy $\times 0.82$ or negative residual energy $/ 1.12\left(\mathrm{NE}_{\mathrm{L}}\right.$ basis $)$.

${ }^{7} \mathrm{NE}_{\mathrm{L}}=0.080 \times \mathrm{BW}^{0.75}+$ milk energy + tissue energy corrected for efficiency of conversion to milk energy (NRC, 2001). 


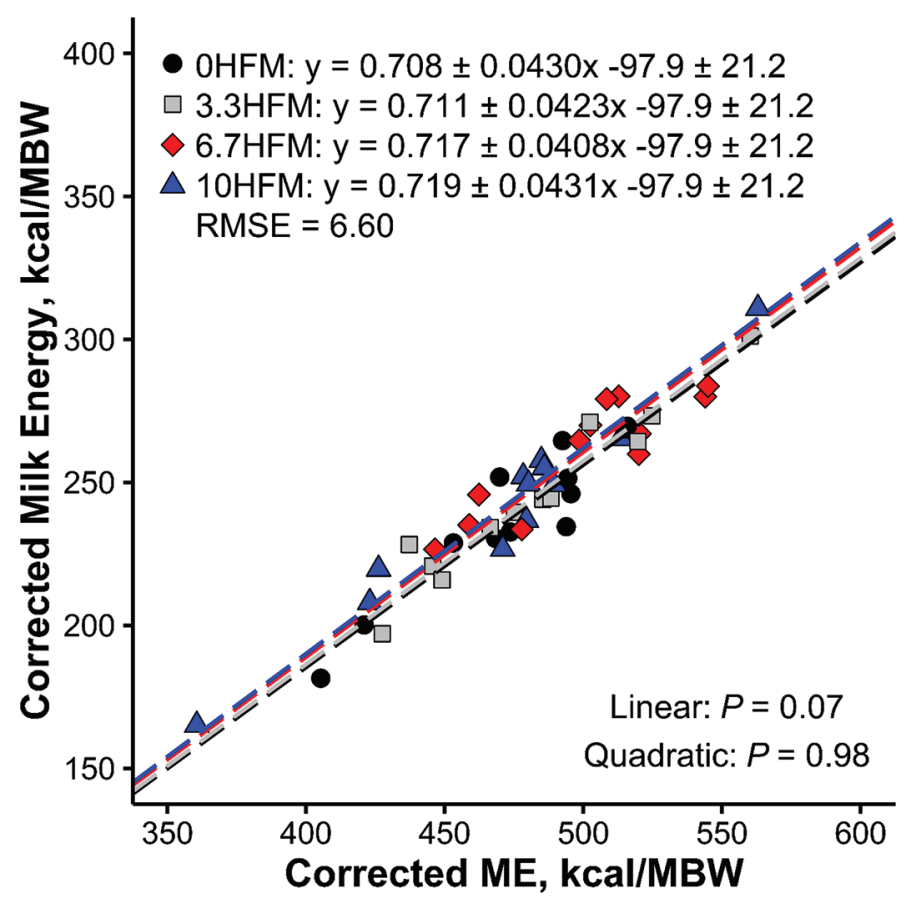

Figure 1. Regression of lactation energy corrected for tissue mobilization on ME intake corrected for tissue retention (see Materials and Methods). Both variables are expressed per unit of metabolic body weight (MBW). The effect of treatment, which represents treatment differences in $\mathrm{NE}_{\mathrm{M}}$, was not significant $(P=0.55)$ and was thus removed. The $\mathrm{NE}_{\mathrm{M}}$ was $97.9 \pm 21.2 \mathrm{kcal} / \mathrm{MBW}$. The slope of each regression represents $\mathrm{k}_{\mathrm{L}}$ (efficiency of utilizing $\mathrm{ME}$ intake for milk production). $0 \mathrm{HFM}=0 \%$ hydrolyzed feather meal; $3.3 \mathrm{HFM}=3.3 \%$ hydrolyzed feather meal; 6.7HFM $=6.7 \%$ hydrolyzed feather meal; $10 \mathrm{HFM}=10 \%$ hydrolyzed feather meal; RMSE $=$ root mean square error.

efficient compared with milk protein. Approximately $50 \%$ of milk fat is preformed fatty acid (Bauman and Griinari, 2003), which has a theoretical energetic efficiency of 94 to $97 \%$ (Baldwin et al., 1985). Consequently, the incorporation of preformed fat into milk will decrease the overall heat load associated with milk fat synthesis compared with milk protein synthesis. In this experiment, we demonstrate that $\mathrm{k}_{\mathrm{L}}$ can differ by dietary treatments, as has been suggest for changes in dietary chemical composition (VandeHaar, 1998; NRC, 2001; Moraes et al., 2015). Therefore, the use of static $\mathrm{k}_{\mathrm{L}}$ values may misrepresent the biology underlying the transformation of $\mathrm{ME}$ to $\mathrm{NE}_{\mathrm{L}}$ in lactating dairy cows.

\section{Nutrient Digestibility and Nitrogen Utilization}

Increasing inclusion of HFM linearly increased $(P<$ 0.04 ) total-tract digestibility of NDF, and starch (Table 4). Modest improvements in NDF digestibility with increased HFM may have occurred due to an increase in the RDP content from 8.1 to $8.8 \%$ of the diet DM for $0 \mathrm{HFM}$ and 10HFM, respectively. Estimated RDP content increased with HFM because compared with blood meal and nonenzymatically browned soybean meal, the ingredient is more degradable in the rumen (NRC, 2001). It is well established that feeding diets low in RDP can decrease NDF digestibility (Colmenero and Broderick, 2006; Lee et al., 2012). Although an increase in starch digestibility with HFM inclusion was not expected, it is also possible that increased supply of RDP may have supported a more favorable rumen environment (Russell et al., 1992) leading to increased ruminal degradation of starch. Apparent total-tract digestibility of $\mathrm{CP}$ linearly decreased $(P<0.01)$ with increasing HFM inclusion. This was likely due to a lower digestibility of RUP contained in HFM (65\%) compared with blood meal $(80 \%)$ and nonenzymatically browned soybean meal (93\%; NRC, 2001). Decreased CP digestibility with increased HFM inclusion is supported by in vitro estimated total-tract $\mathrm{CP}$ digestibility for the 3 RUP sources $(50.3 \pm 1.98,94.3$, and 98.0 for HFM, blood meal, and nonenzymatically browned soybean meal, respectively). Waltz et al. (1989) reported that feeding HFM to replace of blood meal decreased apparent total-tract CP digestibility (63.4 vs. $73.9 \%)$ and AA absorption in the small intestine (65.4 vs. $78.5 \%$ ). Increasing inclusion of HFM linearly increased $(P<$ 0.04 ) digestibility of total fatty acids, $16 \mathrm{C}$ fatty acids, and $18 \mathrm{C}$ fatty acids. This response indicates that the fat in HFM is highly digestible. An increase in dietary content of cis-9 C18:1 with increasing $\operatorname{HFM}(0.85,0.90$, 0.95 , and $1.01 \%$ of DM for 0HFM, 3.3HFM, 6.7MFM, and $10 \mathrm{HFM}$, respectively) may have increased fatty acid digestibility. de Souza et al. (2019) reported that increasing cis-9 C18:1 from 0.68 to $0.98 \%$ of diet DM linearly increased digestibility of total, $16-\mathrm{C}$, and 18-C fatty acids.

Digested $\mathrm{N}$ is partitioned toward productive, maintenance, or metabolic functions and may be influenced by diet. In the current study, $\mathrm{N}$ intake quadratically increased $(P<0.01)$ from 0HFM to 6.7HFM and decreased for 10HFM (Table 5). A similar quadratic response $(P<0.01)$ was observed for fecal $\mathrm{N}$ excretion. The observed responses in $\mathrm{N}$ intake and fecal $\mathrm{N}$ excretion can be explained by an increase in dietary CP content with increased HFM inclusion and a similar quadratic relationship for DMI with increasing HFM inclusion (see later discussion). As HFM inclusion increased, linear decreases $(P<0.01)$ were observed for urinary $\mathrm{N}$ excretion. Decreased $\mathrm{N}$ digestibility in the current study may explain why urinary $\mathrm{N}$ excretion decreased with increasing HFM. Because MP supply is a function of intestinal digestibility of protein, decreased $\mathrm{N}$ digestibility will lead to decreased MP supply. As 
Table 4. Effects of treatments containing hydrolyzed feather meal fed to lactating Jersey cows on total-tract digestibility (\%)

\begin{tabular}{|c|c|c|c|c|c|c|c|c|}
\hline \multirow[b]{2}{*}{ Item } & \multicolumn{4}{|c|}{ Treatment $^{1,2}$} & \multirow[b]{2}{*}{ SEM } & \multicolumn{3}{|c|}{$P$-value ${ }^{3}$} \\
\hline & OHFM & 3.3HFM & 6.7HFM & 10HFM & & $\mathrm{L}$ & Q & $\mathrm{C}$ \\
\hline $\mathrm{DM}$ & 65.9 & 65.7 & 66.1 & 66.0 & 0.77 & 0.68 & 0.94 & 0.61 \\
\hline $\mathrm{OM}$ & 68.0 & 67.8 & 68.2 & 68.0 & 0.77 & 0.84 & 0.96 & 0.54 \\
\hline NDF & 45.6 & 45.6 & 47.6 & 48.7 & 1.38 & $<0.01$ & 0.63 & 0.56 \\
\hline $\mathrm{CP}$ & 63.4 & 61.1 & 59.9 & 58.6 & 1.46 & $<0.01$ & 0.45 & 0.70 \\
\hline Starch & 96.3 & 96.4 & 97.2 & 97.1 & 0.61 & 0.04 & 0.80 & 0.31 \\
\hline Total fatty acids & 77.2 & 77.7 & 78.5 & 80.6 & 1.30 & $<0.01$ & 0.38 & 0.75 \\
\hline 16C fatty acids & 78.3 & 79.2 & 80.4 & 82.4 & 1.19 & $<0.01$ & 0.48 & 0.93 \\
\hline 18C fatty acids & 79.6 & 80.0 & 80.3 & 82.3 & 1.32 & 0.04 & 0.35 & 0.63 \\
\hline Energy & 65.8 & 65.8 & 66.2 & 66.1 & 0.838 & 0.52 & 0.86 & 0.67 \\
\hline
\end{tabular}

${ }^{1}$ Treatments: $0 \mathrm{HFM}=0 \%$ hydrolyzed feather meal; $3.3 \mathrm{HFM}=3.3 \%$ hydrolyzed feather meal; $6.7 \mathrm{HFM}=6.7 \%$ hydrolyzed feather meal; $10 \mathrm{HFM}=10 \%$ hydrolyzed feather meal.

${ }^{2}$ Least squares means; largest standard error of treatment mean is shown.

${ }^{3} \mathrm{~L}=$ linear; $\mathrm{Q}=$ quadratic; $\mathrm{C}=$ cubic.

MP supply decreases, the efficiency of MP use for milk protein synthesis increases (Moraes et al., 2018), and thus catabolism of protein will decrease, leading to decreased urinary $\mathrm{N}$ excretion. We observed a cubic response $(P=0.02)$ for $\mathrm{N}$ balance $(-27,9,-24$, and 11 $\pm 22.5 \mathrm{~g} / \mathrm{d}$ for 0HFM, 3.3HFM, 6.7MFM, and 10HFM, respectively), which was not expected and is difficult to explain. A variety of methodological issues contribute to error in estimation of $\mathrm{N}$ balance, including underacidification of urine and $\mathrm{N}$ volatilization during drying (Spanghero and Kowalski, 1997). Together these errors could contribute to an overestimation of $\mathrm{N}$ balance, which, in the current experiment, averaged $-8 \mathrm{~g} / \mathrm{d}$. Although this is a biologically feasible value, it should be noted that a N-balance of near zero does not necessarily indicate accuracy in the values used to calculate N-balance.

\section{DMI, Milk Yield, and Milk Composition}

Decreased DMI has been observed when HFM is fed to lactating dairy cows (Yeo et al., 2003; Stahel et al., 2014; Giallongo et al., 2017); however, this response is not always observed (Harris et al., 1992; Grant and Haddad, 1998). We observed that increasing HFM inclusion quadratically increased $(P=0.03)$ DMI from OHFM to 6.7HFM, but decreased DMI for 10HFM (Table 6). In the current study, because estimated supply of Lys and His decreased with increasing HFM (see Table 2), a deficiency in one or both of these AA may have caused the decreased DMI for 10HFM. Imbalance in AA supply in nonruminants has been shown to consistently reduce DMI and this response is mediated by appetite centers in the brain (Gietzen, 1993). Giallongo et al. (2017) observed decreased DMI when HFM was

Table 5. Effects of treatments containing hydrolyzed feather meal fed to lactating Jersey cows on nitrogen utilization

\begin{tabular}{|c|c|c|c|c|c|c|c|c|}
\hline \multirow[b]{2}{*}{ Item } & \multicolumn{4}{|c|}{ Treatment $^{1,2}$} & \multirow[b]{2}{*}{ SEM } & \multicolumn{3}{|c|}{$P$-value ${ }^{3}$} \\
\hline & OHFM & $3.3 \mathrm{HFM}$ & $6.7 \mathrm{HFM}$ & $10 \mathrm{HFM}$ & & $\mathrm{L}$ & Q & $\mathrm{C}$ \\
\hline \multicolumn{9}{|l|}{ Mass, g/d } \\
\hline $\mathrm{N}$ intake & 535 & 576 & 577 & 550 & 23.8 & 0.36 & $<0.01$ & 0.78 \\
\hline Fecal N & 199 & 230 & 239 & 237 & 12.1 & $<0.01$ & $<0.01$ & 0.64 \\
\hline Urinary $\mathrm{N}$ & 166 & 151 & 155 & 119 & 14.8 & $<0.01$ & 0.22 & 0.19 \\
\hline Milk N & 198 & 186 & 207 & 184 & 15.0 & 0.59 & 0.52 & 0.06 \\
\hline $\mathrm{N}$ balance & -27 & 9 & -24 & 11 & 22.5 & 0.13 & 0.96 & 0.02 \\
\hline \multicolumn{9}{|c|}{ Proportion of $\mathrm{N}$ intake, $\%$} \\
\hline Fecal N & 37.2 & 39.8 & 41.3 & 42.7 & 1.04 & $<0.01$ & 0.39 & 0.71 \\
\hline Urinary $\mathrm{N}$ & 30.7 & 26.3 & 27.0 & 21.6 & 2.39 & $<0.01$ & 0.74 & 0.12 \\
\hline Milk N & 37.0 & 33.0 & 36.1 & 33.7 & 3.30 & 0.24 & 0.54 & 0.04 \\
\hline $\mathrm{N}$ balance & -5.0 & 1.0 & -4.4 & 2.0 & 3.96 & 0.09 & 0.90 & 0.02 \\
\hline
\end{tabular}


$=10 \%$ hydrolyzed feather meal.

${ }^{2}$ Least squares means; largest standard error of treatment mean is shown.

${ }^{3} \mathrm{~L}=$ linear; $\mathrm{Q}=$ quadratic; $\mathrm{C}=$ cubic. 
Table 6. Effects of treatments containing hydrolyzed feather meal fed to lactating Jersey cows on DMI, milk production and composition, free water intake, BW, and BCS

\begin{tabular}{|c|c|c|c|c|c|c|c|c|}
\hline \multirow[b]{2}{*}{ Item } & \multicolumn{4}{|c|}{ Treatment $t^{1,2}$} & \multirow[b]{2}{*}{ SEM } & \multicolumn{3}{|c|}{$P$-value ${ }^{3}$} \\
\hline & OHFM & $3.3 \mathrm{HFM}$ & 6.7HFM & $10 \mathrm{HFM}$ & & $\mathrm{L}$ & $\mathrm{Q}$ & $\mathrm{C}$ \\
\hline Milk yield, kg/d & 31.7 & 32.0 & 31.9 & 29.7 & 1.32 & 0.04 & 0.06 & 0.54 \\
\hline $\mathrm{ECM},{ }^{4} \mathrm{~kg} / \mathrm{d}$ & 39.7 & 39.6 & 40.1 & 37.8 & 1.54 & 0.13 & 0.15 & 0.31 \\
\hline $\mathrm{ECM} / \mathrm{DMI}$ & 2.03 & 1.98 & 1.98 & 1.98 & 0.086 & 0.40 & 0.51 & 0.77 \\
\hline Fat, \% & 5.35 & 5.23 & 5.45 & 5.54 & 0.209 & 0.04 & 0.22 & 0.23 \\
\hline Protein, $\mathrm{kg} / \mathrm{d}$ & 1.05 & 1.05 & 1.02 & 0.96 & 0.040 & $<0.01$ & 0.14 & 0.77 \\
\hline Lactose, $\%$ & 4.84 & 4.84 & 4.86 & 4.84 & 0.052 & 0.87 & 0.80 & 0.51 \\
\hline Lactose, $\mathrm{kg} / \mathrm{d}$ & 1.54 & 1.55 & 1.55 & 1.44 & 0.072 & 0.09 & 0.098 & 0.50 \\
\hline MUN, mg/dL & 15.1 & 14.7 & 14.7 & 14.4 & 0.683 & 0.11 & 0.91 & 0.47 \\
\hline Free water intake, L/d & 88.9 & 91.0 & 93.6 & 87.4 & 6.08 & 0.91 & 0.19 & 0.51 \\
\hline $\mathrm{BW}, \mathrm{kg}$ & 444 & 445 & 451 & 441 & 13 & 0.61 & 0.01 & 0.02 \\
\hline $\mathrm{BCS}$ & 3.10 & 2.98 & 3.13 & 3.04 & 0.16 & 0.86 & 0.68 & 0.04 \\
\hline
\end{tabular}

${ }^{1}$ Treatments: $0 \mathrm{HFM}=0 \%$ hydrolyzed feather meal; $3.3 \mathrm{HFM}=3.3 \%$ hydrolyzed feather meal; $6.7 \mathrm{HFM}=6.7 \%$ hydrolyzed feather meal; $10 \mathrm{HFM}$ $=10 \%$ hydrolyzed feather meal.

${ }^{2}$ Least squares means; largest standard error of treatment mean is shown.

${ }^{3} \mathrm{~L}=$ linear; $\mathrm{Q}=$ quadratic $\mathrm{C}=$ cubic.

${ }^{4} \mathrm{ECM}=0.327 \times$ milk yield $(\mathrm{kg})+12.95 \times$ fat $(\mathrm{kg})+7.20 \times$ true protein $(\mathrm{kg})($ Tyrrell and Reid, 1965).

fed at $2.7 \%$ of diet DM and fully replaced blood meal; however, supplementation of rumen-protected His to their HFM diet increased DMI.

Feeding increasing HFM quadratically increased $(P=$ 0.06) milk yield from 0HFM to 6.7HFM, but decreased milk yield for 10HFM. Milk fat concentration linearly increased $(P=0.04)$ with increasing HFM, which may have occurred due to increased dietary $\mathrm{NE}_{\mathrm{L}}$ content. However, milk fat yield was not observed to differ $(P$ $>0.34$; averaging $1.68 \pm 0.082 \mathrm{~kg} / \mathrm{d})$. Increasing diet HFM content linearly decreased $(P<0.04)$ milk protein concentration and milk protein yield. Harris et al. (1992) observed that increasing HFM linearly decreased milk protein concentration when feeding HFM at 0,3 , or $6 \%$ of diet DM as a replacement for soybean meal. Supply of Lys and His may have an effect on milk protein concentration and yield (NRC, 2001; Giallongo et al., 2016; Zang et al., 2019). For HFM, the Lys (2.57\% of CP) and His (1.15\% of CP) content are low compared with blood meal (8.98 and $6.36 \%$ of CP for Lys and His, respectively) and nonenzymatically browned soybean meal (5.78 and $2.40 \%$ of CP for Lys and His, respectively; NRC, 2001). The recommended supplies are $6.6 \%$ of MP for Lys (Schwab et al., 2005) and 2.2\% of MP for His (Lee et al., 2012). For all diets in the current experiment, estimated Lys supply was less than $6.6 \%$ of MP, and for 6.7HFM and 10HFM, estimated His supply was less than $2.2 \%$ of MP. Therefore, a deficiency in available Lys, His, or both may have caused decreased milk protein and research is needed to understand how increased supply of Lys and His in HFM diets affects milk production and composition. Although milk protein yield linearly decreased with increasing HFM, and the lowest feed intake was observed for the 10 HFM treatment, ECM was not affected $(P>0.12)$ by HFM (average of $39.3 \pm 1.54 \mathrm{~kg} / \mathrm{d}$ ). An increase in dietary energy content with increasing HFM inclusion may have supported sustained milk yield when DMI decreased for 10HFM.

\section{CONCLUSIONS}

A study utilizing lactating dairy cows was conducted to evaluate the effects of increasing the inclusion of HFM on energy utilization, nutrient digestibility, N utilization, DMI, and milk production and composition. This research indicated that increasing dietary inclusion of HFM increased diet energy content and efficiency of utilizing energy for milk production. Increasing HFM decreased CP digestibility, leading to increased fecal $\mathrm{N}$ excretion. When HFM was fed up to $6.7 \%$ of the diet DM, DMI was maintained; however, milk protein content and yield decreased with increasing HFM. Decreased DMI with inclusion of 10\% HFM and decreased milk protein with increasing HFM may have been due to deficiency in Lys, His, or both, and research is needed to test the effects of increased Lys and His supply in diets with HFM. 


\section{ACKNOWLEDGMENTS}

The authors thank the University of Nebraska Dairy Metabolism (Lincoln, NE) staff and students for care of the experimental animals and assistance with collections. The authors also thank the Poultry Protein $\&$ Fat Council (Tucker, GA) for funding. The authors have not stated any conflicts of interest.

\section{REFERENCES}

Andrew, S. M., H. Tyrrell, C. Reynolds, and R. Erdman. 1991. Net energy for lactation of calcium salts of long-chain fatty acids for cows fed silage-based diets. J. Dairy Sci. 74:2588-2600. https://doi .org/10.3168/jds.S0022-0302(91)78437-3.

AOAC International. 2000. AOAC International. Official Methods of Analysis. Vol. 1 and 2. 17th ed. AOAC International, Gaithersburg, MD.

Association of American Feed Control Officials (AAFCO). 2016. Official publication. Assoc. Am. Feed Control Officials, Champaign, IL.

Baldwin, B., N. Forsberg, and C. Hu. 1985. Potential for altering energy partition in the lactating cow. J. Dairy Sci. 68:3394-3402. https://doi.org/10.3168/jds.S0022-0302(85)81252-2.

Bauman, D. E., and J. M. Griinari. 2003. Nutritional regulation of milk fat synthesis. Annu. Rev. Nutr. 23:203-227. https://doi.org/ 10.1146/annurev.nutr.23.011702.073408.

Bradford, B. J., and C. R. Mullins. 2012. Invited review: Strategies for promoting productivity and health of dairy cattle by feeding nonforage fiber sources. J. Dairy Sci. 95:4735-4746. https://doi .org/10.3168/jds.2012-5393.

Brouwer, E. 1965. Report of sub-committee on constants and factors. Pages 441-443 in Proc. 3rd Symposium of Energy Metabolism. Academic Press, London, UK.

Buse, K. K., D. L. Morris, and P. J. Kononoff. 2019. Ruminal degradation and intestinal digestibility of hydrolyzed feather meal with and without blood. J. Dairy Sci. 102(Suppl. 2):M14. (Abstr.)

Capper, J. L., R. A. Cady, and D. E. Bauman. 2009. The environmental impact of dairy production: 1944 compared with 2007. J. Anim. Sci. 87:2160-2167. https://doi.org/10.2527/jas.2009-1781.

Colmenero, J. J.., and G. Broderick. 2006. Effect of dietary crude protein concentration on milk production and nitrogen utilization in lactating dairy cows. J. Dairy Sci. 89:1704-1712. https://doi.org/ 10.3168/jds.S0022-0302(06)72238-X.

Cotanch, K., R. Grant, H. Dann, and J. Darrah. 2007. Analysis of nutrient composition of feather meal and feather meal with blood. Accessed Sep. 18, 2019. www.poultryegg.com/PPFC/docs/ ProjectR54.pdf.

de Souza, J., N. R. St-Pierre, and A. L. Lock. 2019. Altering the ratio of dietary C16:0 and cis-9 C18:1 interacts with production level in dairy cows: Effects on production responses and energy partitioning. J. Dairy Sci. 102:9842-9856. https://doi.org/10.3168/jds.2019 -16374 .

DuBois, M., K. A. Gilles, J. K. Hamilton, P. Rebers, and F. Smith. 1956. Colorimetric method for determination of sugars and related substances. Anal. Chem. 28:350-356. https://doi.org/10.1021/ ac60111a017.

Foth, A. J., T. Brown-Brandl, K. J. Hanford, P. S. Miller, G. Garcia Gomez, and P. J. Kononoff. 2015. Energy content of reduced-fat dried distillers grains with solubles for lactating dairy cows. J. Dairy Sci. 98:7142-7152. https://doi.org/10.3168/jds.2014-9226.

Freetly, H. C., J. Nienaber, and T. Brown-Brandl. 2006. Partitioning of energy during lactation of primiparous beef cows. J. Anim. Sci. 84:2157-2162. https://doi.org/10.2527/jas.2005-534.

Giallongo, F., M. T. Harper, J. Oh, J. C. Lopes, H. Lapierre, R. A. Patton, C. Parys, I. Shinzato, and A. N. Hristov. 2016. Effects of rumen-protected methionine, lysine, and histidine on lactation performance of dairy cows. J. Dairy Sci. 99:4437-4452. https://doi .org/10.3168/jds.2015-10822.

Giallongo, F., M. T. Harper, J. Oh, C. Parys, I. Shinzato, and A. N. Hristov. 2017. Histidine deficiency has a negative effect on lactational performance of dairy cows. J. Dairy Sci. 100:2784-2800. https://doi.org/10.3168/jds.2016-11992.

Gietzen, D. W. 1993. Neural mechanisms in the responses to amino acid deficiency. J. Nutr. 123:610-625. https://doi.org/10.1093/jn/ 123.4.610.

Goering, H. K., and P. J. Van Soest. 1970. Forage fiber analyses. USDA Agricultural Research Service handbook no. 379. US Government Printing Office, Washington, DC.

Grant, R. J., and S. Haddad. 1998. Effect of a mixture of feather and blood meals on lactational performance of dairy cows. J. Dairy Sci. 81:1358-1363. https://doi.org/10.3168/jds.S0022-0302(98)75699 $-1$.

Hall, M. B. 2009. Analysis of starch, including maltooligosaccharides, in animal feeds: A comparison of methods and a recommended method for AOAC collaborative study. J. AOAC Int. 92:42-49.

Harris, B. Jr., D. Dorminey, W. Smith, H. Van Horn, and C. Wilcox. 1992. Effects of feather meal at two protein concentrations and yeast culture on production parameters in lactating dairy cows. J. Dairy Sci. 75:3524-3530. https://doi.org/10.3168/jds.S0022 -0302(92)78128-4.

Heinrichs, A. J., and P. J. Kononoff. 2002. Evaluating particle size of forages and TMRs using the new Penn State Forage Particle Separator. Technical bulletin DAS 02-42. College Agric. Sci., Cooperative Ext., Pennsylvania State University, University Park.

Karlsson, J., R. Sporndly, M. Lindberg, and K. Holtenius. 2018. Replacing human-edible feed ingredients with by-products increases net food production efficiency in dairy cows. J. Dairy Sci. 101:7146-7155. https://doi.org/10.3168/jds.2017-14209.

Kebreab, E., J. France, R. Agnew, T. Yan, M. Dhanoa, J. Dijkstra, D. Beever, and C. Reynolds. 2003. Alternatives to linear analysis of energy balance data from lactating dairy cows. J. Dairy Sci 86:2904-2913. https://doi.org/10.3168/jds.S0022-0302(03)73887 $-9$.

Kononoff, P. J., and K. J. Hanford. 2006. Technical note: Estimating statistical power of mixed models used in dairy nutrition experiments. J. Dairy Sci. 89:3968-3971. https://doi.org/10.3168/jds .S0022-0302(06)72439-0.

Kuznetsova, A., P. B. Brockhoff, and R. H. B. Christensen. 2017. lmerTest package: tests in linear mixed effects models: Version 3.0-1. Accessed Oct. 10, 2018. https://cran.r-project.org/web/ packages/lmerTest/index.html.

Lee, C., A. N. Hristov, K. S. Heyler, T. W. Cassidy, H. Lapierre, G. A. Varga, and C. Parys. 2012. Effects of metabolizable protein supply and amino acid supplementation on nitrogen utilization, milk production, and ammonia emissions from manure in dairy cows. J. Dairy Sci. 95:5253-5268. https://doi.org/10.3168/jds.2012-5366.

Lenth, R. 2018. Emmeans: Estimated marginal means, aka least squares means. Version 1.4.3.01. Accessed Oct. 10, 2019. https:// cran.r-project.org/web/packages/emmeans/index.html.

McLean, J., and G. Tobin. 1987. Animal and Human Calorimetry. Cambridge University Press, Cambridge, UK.

Moe, P. W., W. P. Flatt, and H. F. Tyrrell. 1972. Net energy value of feeds for lactation. J. Dairy Sci. 55:945-958. https://doi.org/10 .3168/jds.S0022-0302(72)85601-7.

Moraes, L. E., E. Kebreab, J. L. Firkins, R. R. White, R. Martineau, and H. Lapierre. 2018. Predicting milk protein responses and the requirement of metabolizable protein by lactating dairy cows. J. Dairy Sci. 101:310-327. https://doi.org/10.3168/jds.2016-12507.

Moraes, L. E., E. Kebreab, A. B. Strathe, J. Dijkstra, J. France, D. P. Casper, and J. G. Fadel. 2015. Multivariate and univariate analysis of energy balance data from lactating dairy cows. J. Dairy Sci. 98:4012-4029. https://doi.org/10.3168/jds.2014-8995.

Nienaber, J., and A. Maddy. 1985. Temperature controlled multiple chamber indirect calorimeter-design and operation. Trans. ASAE 28:555-0560. https://doi.org/10.13031/2013.32297. 
NRC. 2001. Nutrient Requirements of Dairy Cattle. 7th rev. ed. Natl. Acad. Sci., Washington, DC.

Purwanto, B., Y. Abo, R. Sakamoto, F. Furumoto, and S. Yamamoto. 1990. Diurnal patterns of heat production and heart rate under thermoneutral conditions in Holstein Friesian cows differing in milk production. J. Agric. Sci. 114:139-142. https://doi.org/10 $.1017 /$ S0021859600072117.

Rakes, A., D. Davenport, J. Pettyjohn, and A. Linnerud. 1968. Hydrolyzed feather meal as a protein supplement for lactating dairy cows. J. Dairy Sci. 51:1701-1702. https://doi.org/10.3168/jds .S0022-0302(68)87256-X.

Reynolds, C. K., H. F. Tyrrell, and P. J. Reynolds. 1991. Effects of diet forage-to-concentrate ratio and intake on energy metabolism in growing beef heifers: whole body energy and nitrogen balance and visceral heat production. J. Nutr. 121:994-1003. https://doi .org/10.1093/jn/121.7.994.

Ross, D., M. Gutierrez-Botero, and M. E. Van Amburgh. 2013. Development of an in vitro intestinal digestibility assay for ruminant feeds. Pages 190-202 in Proceedings of the Cornell Nutrition Conference for Feed Manufacturers. Cornell Univ., Ithaca, NY.

Russell, J. B., J. D. O'Connor, D. G. Fox, P. J. Van Soest, and C. J. Sniffen. 1992. A net carbohydrate and protein system for evaluating cattle diets: I. Ruminal fermentation. J. Anim. Sci. 70:35513561. https://doi.org/10.2527/1992.70113551x.

Salami, S. A., G. Luciano, M. N. O'Grady, L. Biondi, C. J. Newbold, J. P. Kerry, and A. Priolo. 2019. Sustainability of feeding plant by-products: A review of the implications for ruminant meat production. Anim. Feed Sci. Technol. 251:37-55. https://doi.org/10 .1016/j.anifeedsci.2019.02.006.

Schwab, C., P. Huhtanen, C. Hunt, and T. Hvelplund. 2005. Nitrogen requirements of cattle. Pages 13-70 in Nitrogen and Phosphorus Nutrition of Cattle and Environment. CAB Int., Wallingford, UK.

Spanghero, M., and Z. M. Kowalski. 1997. Critical analysis of N balance experiments with lactating cows. Livest. Prod. Sci. 52:113122. https://doi.org/10.1016/S0301-6226(97)00138-3.

Stahel, P., N. Purdie, and J. Cant. 2014. Use of dietary feather meal to induce histidine deficiency or imbalance in dairy cows and effects on milk composition. J. Dairy Sci. 97:439-445. https://doi.org/10 $.3168 /$ jds.2013-7269.

Tyrrell, H. F., and J. T. Reid. 1965. Prediction of the energy value of cow's milk. J. Dairy Sci. 48:1215-1223. https://doi.org/10.3168/ jds.S0022-0302(65)88430-2. van Knegsel, A. T., H. Van den Brand, J. Dijkstra, W. Van Straalen, M. Heetkamp, S. Tamminga, and B. Kemp. 2007. Dietary energy source in dairy cows in early lactation: energy partitioning and milk composition. J. Dairy Sci. 90:1467-1476. https://doi.org/10 .3168/jds.S0022-0302(07)71632-6.

Van Soest, P. J., J. B. Robertson, and B. A. Lewis. 1991. Methods for dietary fiber, neutral detergent fiber, and nonstarch polysaccharides in relation to animal nutrition. J. Dairy Sci. 74:3583-3597. https://doi.org/10.3168/jds.S0022-0302(91)78551-2.

VandeHaar, M. J. 1998. Symposium: Efficiency of production - Efficiency of nutrient use and relationship to profitability on dairy farms. J. Dairy Sci. 81:272-282. https://doi.org/10.3168/jds.S0022 -0302(98)75576-6.

VandeHaar, M. J., and N. St-Pierre. 2006. Major advances in nutrition: relevance to the sustainability of the dairy industry. J. Dairy Sci. 89:1280-1291. https://doi.org/10.3168/jds.S0022-0302(06)72196 -8 .

Waltz, D. M., M. D. Stern, and D. Illg. 1989. Effect of ruminal protein degradation of blood meal and feather meal on the intestinal amino acid supply to lactating cows. J. Dairy Sci. 72:1509-1518. https://doi.org/10.3168/jds.S0022-0302(89)79261-4.

Wolf, C. A. 2010. Understanding the milk-to-feed price ratio as a proxy for dairy farm profitability. J. Dairy Sci. 93:4942-4948. https://doi .org/10.3168/jds.2009-2998.

Yeo, J.-M., C. Knight, and D. Chamberlain. 2003. Effects of changes in dietary amino acid balance on milk yield and mammary function in dairy cows. J. Dairy Sci. 86:1436-1444. https://doi.org/10 .3168/jds.S0022-0302(03)73727-8.

Zang, Y., L. H. P. Silva, M. Ghelichkhan, M. Miura, N. L. Whitehouse, M. L. Chizzotti, and A. F. Brito. 2019. Incremental amounts of rumen-protected histidine increase plasma and muscle histidine concentrations and milk protein yield in dairy cows fed a metabolizable protein-deficient diet. J. Dairy Sci. 102:4138-4154. https:// doi.org/10.3168/jds.2018-15780.

\section{ORCIDS}

D. L. Morris $\odot$ https://orcid.org/0000-0001-6347-2804

P. J. Kononoff $\odot$ https://orcid.org/0000-0001-6069-2174 